\title{
Comparison of Preventive and Therapeutic Transplantations of Allogeneic Mesenchymal Stem Cells in Healing of the Distal Femoral Growth Plate Cartilage Defects in Miniature Pigs
}

\author{
Ladislav Plánka ${ }^{1}$, David Starý ${ }^{1}$, Jana Hlučilová ${ }^{3}$, Jiří Klíma ${ }^{3}$, Josef Jančáŕ ${ }^{4}$, Leoš Křen ${ }^{5}$, \\ Jana Lorenzová ${ }^{2}$, Lucie Urbanová ${ }^{2}$, Michal Crha², Robert $\mathrm{Srnec}^{2}$, Milan Dvořák ${ }^{2}$, \\ Petr Gál ${ }^{1}$, Alois Nečas ${ }^{2}$
}

${ }^{1}$ Department of Pediatric Surgery, Orthopaedics and Traumatology, Faculty Hospital Brno, Czech Republic ${ }^{2}$ Department of Surgery and Orthopaedics, Small Animal Clinic, Faculty of Veterinary Medicine, University of Veterinary and Pharmaceutical Sciences Brno, Czech Republic

${ }^{3}$ Institute of Animal Physiology and Genetics of the Academy of Sciences of the Czech Republic, Liběchov, Czech Republic

${ }^{4}$ Institute of Brno University of Technology, Czech Republic

${ }^{5}$ Department of Pathology, Faculty Hospital Brno, Czech Republic

Received November 6, 2008

Accepted December 30, 2008

\begin{abstract}
The aim of the study was to verify whether there is a difference in the lengthwise growth of the femurs and in their angular deformity when comparing preventive vs. therapeutic transplantation of allogeneic mesenchymal stem cells (MSCs) to an iatrogenic defect in the distal physis of femur.

Modified composite chitosan/collagen type I scaffold with MSCs was transplanted to an iatrogenically created defect of the growth cartilage in the lateral condyle of the left femur in 20 miniature male pigs. In Group A of animals $(n=10)$ allogeneic MSCs were transplanted immediately after creating the defect in the distal physis of femur (preventive transplantation). In Group B of animals $(n=10)$ the same defect of the growth cartilage was treated by transplantation of allogeneic MSCs four weeks after its creation (therapeutic transplantation), after the excision of the bone bridge that had formed in it.

On average, left femurs with a damaged distal physis and preventively transplanted allogeneic MSCs (Group A) grew during 4 months from transplantation by $0.56 \pm 0.44 \mathrm{~cm}$ more than right femurs without the transplantation of MSCs, whereas left femurs with physeal defects treated with a therapeutic transplantation of allogeneic MSCs (Group B) by $0.14 \pm 0.72 \mathrm{~cm}$ only, compared to right femurs without transplanted MSCs. Four months after preventive transplantation of MSCs (Group A), valgus deformity of the distal part of left femur with the defect was $0.78 \pm 0.82^{\circ}$; in the control group (right femur in the same animal without MSCs transplantation) it was $3.7 \pm 0.82^{\circ}$. After therapeutic transplantation of MSCs (Group B) $0.6 \pm 3.4^{\circ}$, in the control group (right femur in the same animal without MSCs transplantation) it was $2.1 \pm 2.9^{\circ}$.

In all the animals of Groups $\mathrm{A}$ and $\mathrm{B}$, the presence of newly formed hyaline cartilage was confirmed histologically and immunohistochemically. In the distal physis of right femurs with an iatrogenic defect of the growth cartilage without the transplantation of MSCs (control) bone bridge was formed.

Preventive transplantation of allogeneic MSCs into the defect of the distal growth zone of femur appears more suitable compared to the therapeutic transplantation, with regard to the more pronounced lengthwise bone growth. Differences found in the extent of valgus deformity were non-significant comparing preventive and therapeutic transplantations of MSCs.
\end{abstract}

MSCs, growth plate, deformity, bone bridge

Injury of the growth cartilage of the long bones of the extremities usually leads to the formation of a bone bridge between epiphysis and metaphysis of the long bone (Key and Ford 1958; Bright 1974). At the same time, in approximately $25-30 \%$ of cases the lengthwise bone growth is reduced and its angular deformity occurs (Ahn et al. 2004). Besides, in $10 \%$ of these cases, the function of the relevant joint is impaired (Mann and

Address for correspondence:

MUDr. Ladislav Plánka, Ph.D.

Department of Pediatric Surgery, Orthopaedics and Traumatology

Faculty Hospital Brno

Černopolní 9, 61400 Brno

Czech Republic

Phone +420532234360

Fax: +420 532234365

E-mail: lplanka@seznam.cz

http://www.vfu.cz/acta-vet/actavet.htm 
Rajmaira 1990). Surgical interventions for the correction of these conditions are usually demanding (distraction epiphyseolysis, chondrodiatasis, or temporary growth arrest (Lee et al. 1998)). Preventive interventions preventing the bone bridge formation focus on filling the occurred growth cartilage defect mainly with an allogeneic fat graft (Langenskiöld 1981), a graft from the fascia or tendon, or silicone substitutes (Macksoud and Bright 1989). Some studies point out the positive effect of autologous chondrocyte transplantation into the growth cartilage defect (Foster et al. 1990; Lee et al. 1998; Lennox et al. 1983; Gál et al. 2002a). In our previous studies we addressed the issue of transplantation of MSCs into the injured growth plates in pigs, mainly with the aim to find a suitable scaffold, and also to verify the possibilities and evaluate some aspects of autogenous and allogeneic transplantations of mesenchymal stem cells (Plánka et al. 2007; Gál et al. 2007). Treatment of the bone bridge by its excision and transplantation of MSCs was also studied by Hui et al. (2005).

The aim of this experiment was to compare the difference between preventive transplantation of a composite scaffold with allogeneic MSCs into an iatrogenic defect in the physis, performed immediately after the creation of the defect, and their therapeutic transplantation after the excision of the bone bridge, in the sense of evaluating the difference in the lengthwise growth of the relevant bone and the extent of its valgus deformity. We expected the lengthwise growth of the femoral bone to be bigger and the angular deformity to be smaller in the preventive transplantation of mesenchymal stem cells than in the case of their therapeutic transplantation.

\section{Materials and Methods}

As experimental animal the miniature pig was chosen from certified breeding of the Institute of Animal Physiology and Genetics AS CR, v.v.i. The experimental group of 20 pigs was separated into two subgroups: A (preventive transplantation) and B (therapeutic transplantation). The pigs were 3 months old at the time of surgery, average weight $11 \pm 2.7 \mathrm{~kg}$.

Bone marrow blood was aspirated from os illium (tuber coxae ala osis illii) into a $5 \mathrm{ml}$ syringe with $2 \mathrm{ml}$ Dulbecco's Phosphate Buffered Saline (PBS) with 2\% Foetal Bovine Serum (FBS, StemCell Technologies) and $5 \mathrm{IU}$ heparin $/ \mathrm{ml}$ connected with a hypodermic needle $(20 \mathrm{G} / 40 \mathrm{~mm})$. Under sterile conditions the bone marrow blood (about $4 \mathrm{ml}$ ) was deposited over $3 \mathrm{ml}$ of Ficoll-Paque PLUS (StemCell Technologies). After centrifugation at $400 \mathrm{~g}$ for $30 \mathrm{~min}$ at room temperature, the dense gradient separated erythrocytes and granulocytes as a pellet in the bottom part of the tube; mononuclear cells were situated in an opalescent layer between Ficoll and blood plasma. This layer was taken out, washed in a culture medium (see below) and used for propagation under in vitro conditions. The average amount of mononuclear cells from each isolation was $20 \times 10^{6}$ cells. Cell number and viability was analyzed on Vi-CELL (Series Cell Viability Analyzers) and about 90\% of viable cells were detected.

The cultivated cells were tested using the commonly used positive markers of MSCs (CD29, CD44, CD90, CD105 and newly, according to some studies, also CD147). The panel of antibodies used was: anti-CD29 (clone MEM-101A), anti-CD105 (clone MEM 229), anti-CD147 (clone MEM-M6/2, Exbio Praha a.s., Prague, Czech Republic), anti-CD44 (clone IM7), anti-CD90 (clone 5E10, BD Biosciences, San Jose, CA USA), anti-CD45 (clone K252-1E4, AbD Serotec, Kidlington,UK).

Preparation of the stem cells with the scaffold

Cells were seeded in $75 \mathrm{~cm}^{2}$ tissue culture plastic flasks at a density of approximately $5 \times 10^{5} \mathrm{cells} / \mathrm{cm}^{2}$ and cultured at $37{ }^{\circ} \mathrm{C}$ in humidified atmosphere with $5 \%$ of $\mathrm{CO}_{2}$. The culture medium was $\alpha$-MEM medium (Gibco) supplemented with 10\% FBS (Sigma Aldrich) and gentamycin $(50 \mathrm{mg} / \mathrm{ml}$, Sigma Aldrich). After $24 \mathrm{~h}$ of culture, the non-adherent cells were removed and during the subsequent culture (3 weeks) the medium was exchanged every three days. The first colonies of mesenchymal stem cells appeared after 4 to 5 days of culture and $80 \%$ of confluence was achieved after 10 days of culture. Cells were passaged with trypsin $0.5 \%$ trypsin-EDTA solution (Sigma Aldrich) for $5 \mathrm{~min}$ at $37^{\circ} \mathrm{C}$ and replated in $150 \mathrm{~cm}^{2}$ at a density of $5000-6000 \mathrm{cells} / \mathrm{cm}^{2}$.

During the last three days of culture, cells were labelled with nano-particles of iron oxide (Resovist, 0.5 $\mathrm{mmol} \mathrm{Fe} / \mathrm{ml}$, Schering). Resovist was added at a concentration of $1 \mu \mathrm{l} / \mathrm{ml}$ culture medium. For labelling with a fluorescent dye CM-DiI (Molecular Probes) at a concentration of $5 \mu \mathrm{g} / 2,5 \mathrm{ml} \mathrm{PBS}$, cells were harvested on the day of transplantation, incubated for $5 \mathrm{~min}$ at $37^{\circ} \mathrm{C}$ and for $15 \mathrm{~min}$ at $4{ }^{\circ} \mathrm{C}$. At the end of labelling the cells were thoroughly washed in PBS. To induce chondrogenic differentiation (Miura et al. 2002), the labelled cells were given in the differentiation medium composed of $\alpha$-MEM supplemented with $100 \mathrm{ng} / \mathrm{ml}$ recombinant human TGF $\beta_{1}$ (R\&D Systems), $100 \mathrm{nM}$ dexamethasone (Medochemie), $50 \mu \mathrm{g} / \mathrm{ml}$ L-ascorbic acid 2-phosphate (Sigma 
Aldrich), 1\% insulin-transferrin-selenium A (Gibco) for $30 \mathrm{~min}$. Subsequently, the cells were centrifuged at $700 \mathrm{~g}$ for $5 \mathrm{~min}$, and cell pellets were prepared for their deposition in a scaffold.

Gradually testing the suitable composition of a 3-D carrier for MSCs, we developed an optimum appearing variant of a porous cylinder composed of $0.5 \%$ collagen $+30 \%$ chitosan, netted with EDC (1-ethyl-3-(3dimethylaminopropyl)-carbodiimid hydrochloride) and catalysed with NHS (N-hydroxysuccinimide 98\%) with a structure of chitosan nanofibres. For facilitating handling during implantation, cylindrical substrates after lyophilisation were passed on to be seeded with cells in a 96-well plate.

Surgical procedures

All animals were intramuscularly administered tiletamine-zolazepam (Zoletil 100, Virbac, France) at $2 \mathrm{mg} / \mathrm{kg}$ dosing, xylazine (Sedazine, Fort Dodge, USA) in $2 \mathrm{mg} / \mathrm{kg}$ dosing and ketamine (Ketaset, Fort Dodge, USA) in $2 \mathrm{mg} / \mathrm{kg}$ dosing. All substances were administered together in a single syringe. After the start of sedation in 10 min after administration, intravenous catheter with propophol was inserted in the ear vein (Propophol 1\%, Fresenius, Austria) at the dose of $1 \mathrm{mg} / \mathrm{kg}$ and endotracheal tube was inserted in pigs. All pigs were placed into right lateral position and connected to the inhalation circle rebreathing system. They were supplied with a mixture of oxygen and air $(1: 1)$ at the amount of $25 \mathrm{ml} / \mathrm{kg} / \mathrm{min}$. All pigs were connected to a vital functions monitor (Datex Cardocap II, USA). The logged values included heart rate (HR), respiratory rate (RR), mean arterial pressure (MAP), haemoglobin saturation by oxygen $\left(\mathrm{SpO}_{2}\right)$ and end-tidal $\mathrm{CO}_{2}$ concentration $\left(\mathrm{ETCO}_{2}\right)$. HR was measured using a 3-lead EKG with electrodes located on the patient's chest. MAP was measured using a disposable blood pressure transducer connected to a monitor after calibration. The pressure transducer was connected to the arterial access port (a. auricularis on the contralateral ear to the venous access) using extension tubing filled with heparinized saline (200 IU heparin $\cdot \mathrm{ml}^{-1}$, Heparin, Léčiva, Czech Republic). RR and ETCO were logged using side-stream with a sensor connected on the tip of endotracheal tube. $\mathrm{SpO}_{2}$ was measured with a sensor connected to the patient's tongue.

Pigs were placed in dorsal recumbency and the surgical site was routinely prepared for aseptic procedure on both knees. Lateral arthrotomy of the stifle joint was performed by parapatellar incision. After visual localization of the growth plate, the battery-powered drill (Colibri system, SYNTHES, USA) was used to create a defect in the lateral part of the distal femoral physis in order to cause damage exceeding $9 \%$ of the growth plate area (Gál et al. 2002a,b; Janarv et al. 1998). Therefore, a $6 \mathrm{~mm}$ drill bit (Smith and Nephew, USA) was used to bore a canal $16 \mathrm{~mm}$ in depth from the lateral surface of the lateral condyle dorsolaterally above the insertion of m. extensor digitorum longus. The canal was drilled in a dorsomedial direction in order to cause damage of the lateral part of the distal femoral physis including the adjacent parts of epiphysis and metaphysis.

This iatrogenically created defect of the distal physis of the left femur in animals of Groups A and B then served as the site of preventive or therapeutic transplantation of the gel scaffold with allogeneic MSCs. The growth cartilage defect created by the same method in the right femoral bone was left in all the animals of Groups A and $\mathrm{B}$ without the transplantation of MSCs and served in both groups as control.

In Group A of animals (preventive transplantation of MSCs) the scaffold with allogeneic MSCs was transplanted into the defect of the distal physis of the right femur immediately after it was created. A complex of the scaffold and MSCs was prepared in the wells of a microtitration plate (TPT), from where the implant (in the form of a cylinder $6 \mathrm{~mm}$ thick and $10 \mathrm{~mm}$ long) was taken and carefully inserted into the defect drilled in the lateral femoral condyle. In order to fix the transplant in its position, the canal was closed (on the lateral surface of the lateral condyle of femur) with a periosteal suture. The stifle joint was lavaged with Ringer Lactat solution (Ringer Lactat I.V.Inf., Braun Medical AG). The joint capsule was closed with interrupted cross stitches using PDS 0 (PDS, Ethicon). The fascia and subcutaneous layer were sutured with a continuous suture using PDS 2/0 (PDS, Ethicon). The skin was closed with a simple interrupted suture using 3/0 ETHILON (Ethilon, Ethicon).

In animals of Group B (therapeutic transplantation of MSCs) the dilated canal of the iatrogenic defect of the distal physis of the left femur was closed only with a periosteal suture. Four weeks after creating the defect, arthrotomy of the left knee joint was performed by the same method. The bone bridge formed at the site of the original physeal defect was bored off by a drill with a $9 \mathrm{~mm}$ diameter (SYNTHES,Switzerland). Transplantation of the scaffold with MSCs followed using the aforementioned method.

After the surgery, antagonisation of all three anaesthetic components was performed using a combination of naloxon (0.03 mg/kg (INTRENON inj., Léčiva a.s.)) + flumazenil (0.1 mg/kg (ANEXATE, Hoffmann-La Roche Ltd.)) + atipamezol (1.0 mg/kg (ANTISEDAN inj. ad us. vet., Pfizer Animal Health)) administered intramuscularly. Analgesia in the post-operative period was achieved by administration of carprofen (RIMADYL inj. ad us. vet., Pfizer Animal Health) at the dose of $2 \mathrm{mg} / \mathrm{kg}$ /day for three days after the surgery. Following recovery from surgery, the animals were allowed to walk freely and bear weight as tolerated. During the whole study period, the animals were fed, handled and housed according to the principles of welfare (Sýkora et al. 1983). The animals were housed in separate pens (five animals per each), bedding with straw, automatic waterers and their health condition was checked every day. Food was delivered several times a day, the food was BIOSTAN KPB (Biokron s.r.o., Czech Republic) at the dose of $2-3 \mathrm{~kg}$ per pig per day. At the end of the experiment (4 months after the surgery), all animals were euthanized lege artis. First, general anaesthesia was induced using intravenous thiopental at the dose of $20 \mathrm{mg} / \mathrm{kg}$. Then they were given intravenous $\mathrm{T} 61 \mathrm{inj}$. ad us. vet. (Hoechst Roussel Vet.) at the dose of $1 \mathrm{ml}$ pro toto.

The length and angular (valgus) deformity of the operated bones were measured from radiographs in a 
craniocaudal (CC) projection. The quality of transplant incorporation was evaluated histologically. The presence of transplanted cells in the physis was detected by immunofluorescence. All procedures were carried out with the consent of the Ethics Committee (No. 46613/2003-1020).

Bone length discrepancy and femoral valgus deformity measurements

Each pig was subjected to radiological examination on the day of transplantation and immediately after euthanasia. Bone length discrepancy and valgus deformity were measured from radiographs. Measurement of the length of the right femur (with the physeal defect and transplanted MSCs) and the left femur (with the physeal defect without transplanted MSCs) was based on radiographs of the femur in a craniocaudal (CC) projection. The actual length of the femur and the angle of valgus deformity of the distal femur were measured. The measurements were performed separately by three independent observers. The measured values were averaged to calculate the arithmetic mean.

\section{Histological findings}

Defect healing was investigated histologically using haematoxylin and eosin staining. Following the excision of femurs of the euthanized pigs, femoral distal epiphyses were placed in $10 \%$ solution of formalin and stabilized. They were then decalcified and gradually dehydrated in solutions with increasing concentrations of alcohol to enable embedding them in paraffin. Ultrathin paraffin sections of the distal femur $0.10 \mathrm{~mm}$ in thickness were stained with haematoxylin and eosin (HE) and subjected to microscopy. The site of defect in the growth plate of the femur was examined histologically. Collagen II was immunohistochemically detected.

On the basis of immunofluorescence detection of CM-DiI stain incorporated into the cell wall, these examinations should prove whether the chondrocytes present in the defect came from the transplanted colony of allogeneic MSCs or not.

\section{Statistical evaluation}

Means and standard deviations were calculated for the length and valgus deformity of the right femur (with the physeal defect and transplanted MSCs) and the left femur (with the physeal defect without transplanted MSCs) as well as for differences in length and angular deformities before MSCs transplantation and after euthanasia. The values were statistically analyzed using Wilcoxon matched-pairs test; STATISTICA (data analysis software system), version 7.1 (StatSoft, Inc. 2005).

\section{Results}

There were no complications during the collection of bone marrow blood from iliac wings. No pig in either group A or B died. In a total of twenty pigs, we successfully cultured MSCs allotransplants in the required quality with the mean count of cells $16 \times 10^{6}$ $\left(16 \times 10^{6} \pm 14 \times 10^{6}\right)$. The allogeneic MSCs were successfully transplanted into iatrogenic distal femoral physeal defects. The wounds healed per primam intentionem, and no clinical adverse host response to the allogeneic MSC transplantation into iatrogenically damaged physes could be detected. The health condition of all animals was good during the housing period with no complications.

During immunophenotypisation, the expression of the monitored population was more than $98 \%$ in CD29, CD44 a CD90, and may be considered homogenous. In CD105 and CD147 their expression was low.

On average, left femurs with a damaged distal physis and preventively transplanted allogeneic MSCs (Group A) grew during 4 months from transplantation by $0.56 \pm 0.44 \mathrm{~cm}$ more than right femurs without the transplantation of MSCs, whereas left femurs with physeal defects treated with a therapeutic transplantation of allogeneic MSCs (Group B) by $0.14 \pm 0.72 \mathrm{~cm}$ only, compared to right femurs without transplanted MSCs. Thus, femurs subjected to a preventive transplantation of MSCs grew lengthwise more than after therapeutic transplantation $(p=0.00006)$.

Four months after preventive transplantation of MSCs (Group A), valgus deformity of the distal part of left femur with the defect was $0.78 \pm 0.82^{\circ}$; in the control group (right femur in the same animal without MSCs transplantation) it was $3.7 \pm 0.82^{\circ}$. After therapeutic transplantation of MSCs (Group B) $0.6 \pm 3.4^{\circ}$, in the control group (right femur in the same animal without MSCs transplantation) it was $2.1 \pm 2.9^{\circ}$. In this case no significant difference was found in the extent of angular deformity of the distal femur among animals after preventive or therapeutic transplantation of MSCs $(p=0.586)$.

In all the animals of groups A and B in left distal femurs the presence of newly formed hyaline 
cartilage was histologically confirmed at the site of the original growth cartilage defect after the transplantation of allogeneic MSCs (Plate XIII, Fig. 1). Histological examination revealed that the defect was filled with hyaline cartilage in most cases. Immunohistochemical staining was then performed on hyaline cartilage, using type-II collagen antibodies ( $90 \%$ positive) (Plate XIII, Fig. 2). Labelled cells located in the healed defect were demonstrated by immonufluorescence after preventive and therapeutic transplantations of mesenchymal stem cells, with the exception of two cases in Group A and one pig in Group B. In all cases (animals of both Groups A and B) a bone bridge was formed in the distal physis of right femurs with an iatrogenic defect of the growth cartilage without the transplantation of MSCs (control), and it was demonstrated histologically (Plate XIV, Fig. 3).

Table 1. Length and valgus deformity of femurs measured from radiographs - preventive and therapeutic transplantation

\begin{tabular}{|c|c|c|c|c|}
\hline Animal & $\begin{array}{c}\text { Length difference of left } \\
\text { femur from preventive } \\
\text { MSCs transplantation till } \\
\text { euthanasia (cm) }\end{array}$ & $\begin{array}{c}\text { Length difference of right } \\
\text { femur without MSCs } \\
\text { transplantation from start } \\
\text { of experiment till } \\
\text { euthanasia }(\mathrm{cm})\end{array}$ & $\begin{array}{c}\text { Valgus deformity of left } \\
\text { femur from preventive MSCs } \\
\text { transplantation till euthanasia }\left({ }^{\circ}\right)\end{array}$ & $\begin{array}{c}\text { Valgus deformity of right } \\
\text { femur without MSCs } \\
\text { transplantation from start of } \\
\text { experiment till euthanasia }\left(^{\circ}\right)\end{array}$ \\
\hline A1 & 15.8 & 15.1 & 1 & 4 \\
\hline A2 & 14.2 & 13.2 & 0 & 3 \\
\hline A3 & 13.9 & 13.4 & 1 & 4 \\
\hline A4 & 15.1 & 14.6 & 1 & 2 \\
\hline A5 & 14.2 & 13.9 & 1 & 4 \\
\hline A6 & 16.0 & 15.5 & 1 & 3 \\
\hline A7 & 14.9 & 14.4 & 1 & 4 \\
\hline A8 & 13.8 & 13.3 & 1 & 4 \\
\hline A9 & 15.0 & 14.5 & 1 & 4 \\
\hline A10 & 15.7 & 15.1 & 1 & 4 \\
\hline
\end{tabular}

Length and valgus deformity of femurs measured from radiographs in a CC projection in pigs. Left femurs with preventive allogeneic MSCs transplanted into physeal defects; right femurs with physeal defects but without transplanted MSCs (Experimental group A)

Table 2. Length and valgus deformity of femurs measured from radiographs - therapeutic transplantation

\begin{tabular}{|c|c|c|c|c|}
\hline Animal & $\begin{array}{c}\text { Length difference of left } \\
\text { femur from therapeutic } \\
\text { MSCs transplantation till } \\
\text { euthanasia (cm) }\end{array}$ & $\begin{array}{c}\text { Length difference of right } \\
\text { femur without MSCs } \\
\text { transplantation from start } \\
\text { of experiment till } \\
\text { euthanasia }(\mathrm{cm})\end{array}$ & $\begin{array}{c}\text { Valgus deformity of left } \\
\text { femur from therapeutic MSCs } \\
\text { transplantation till euthanasia }\left({ }^{\circ}\right)\end{array}$ & $\begin{array}{c}\text { Valgus deformity of right } \\
\text { femur without MSCs } \\
\text { transplantation from start of } \\
\text { experiment till euthanasia }\left({ }^{\circ}\right)\end{array}$ \\
\hline B 1 & 15.1 & 14.1 & -3 & 2 \\
\hline B 2 & 16.2 & 16.2 & 0 & 3 \\
\hline B 3 & 14.7 & 14.5 & 4 & 2 \\
\hline B 4 & 15.6 & 15.5 & 0 & 0 \\
\hline B 5 & 13 & 14.1 & 0 & 3 \\
\hline B 6 & 16.1 & 15.8 & -1 & 0 \\
\hline B 7 & 16 & 15.8 & 0 & 4 \\
\hline B 8 & 14.8 & 14.7 & 2 & 3 \\
\hline B 9 & 13.8 & 13.4 & 4 & 0 \\
\hline B 10 & 15.1 & 14.9 & 0 & 3 \\
\hline
\end{tabular}

Length and valgus deformity of femurs measured from radiographs in a CC projection in pigs. Left femurs with therapeutic allogeneic MSCs transplanted into physeal defects; right femurs with physeal defects but without transplanted MSCs (Experimental group B) 


\section{Discussion}

In this study mesenchymal stem cells derived from the bone marrow were used (BMMCs, BMMSCs), i.e., from a source most frequently used for obtaining MSCs (Chen et al. 2003; Plánka et al. 2007; Hui et al. 2005). Less frequently MSCs derived from the periosteum (Hui et al. 2005; Hideya et al. 2007), or fat tissue (Hui et al. 2005; Hideya et al. 2007) are used. Successfulness of transplantation varies in individual animal species in dependence on the source of the stem cells (Hideya et al. 2007; Hui et al. 2005). The method of collecting bone marrow blood from the wing of the iliac bone was chosen for the obtaining of MSCs with regard to the high yield and easier processing of the sampled biological material, and also because this method has been practiced at our department for a longer time.

Preparation of the scaffold and MSCs for the transplantation took place in the cytologic laboratory of the Institute of Animal Physiology and Genetics of the Academy of Sciences of the Czech Republic, Liběchov, in cooperation with the Institute of Experimental Medicine of the Academy of Sciences of the Czech Republic, Prague, as per the methodology implemented at these institutes. The issue of differentiation of MSCs into chondrocytes is at present in the phase of searching for the corresponding differentiation factors and the right timing of their effect. This experiment benefited our cytologic laboratory (after previous in vitro tests) by verifying the suitability of the implant (i.e., combination of a gel scaffold with mesenchymal stem cells used for the purpose of new formation of cartilaginous tissue) also in vivo in pigs. Laboratory development of a suitable scaffold is, with regard to our experimental studies on the healing defects of tissues derived from mesoderm, an important part of experiments that are already being conducted or prepared. In this sense, knowledge gained from the development and preparation of a suitable combination of scaffold/MSCs is the connecting link between individual experimental studies. It is likewise important for possible modifications of these biological implants, so that in subsequent experiments focused on the healing of cartilaginous tissue, a suitable carrier and differentiation factors for stimulation of differentiation of MSCs into the target tissue are used. The most frequently used differentiation factors for in vitro as well as in vivo experiments are TGF- $\beta 1$ (Lisignoli et al. 2005; Li et al. 1993; Hui et al. 2005) and TGF- $\beta 3$ (Mackay et al. 1998; Lee et al. 2004; Chen et al. 2004). Differentiation occurs as per various protocols by stimulation directly in the carrier medium at a given concentration and for a certain period (Miura 2002; Lisignoli et al. 2005; Hui et al. 2005). The large family of TGF factors also includes the cartilage-derived morphogenetic protein 1 (CDMP1) that was successfully transferred by genic transfer to the pig BMMSCs and stimulated them successfully to chondrogenesis, which was confirmed immunohistochemically and with Safranin-O stain (Katayama et al. 2004). Part of some protocols is also a combination with BMP types 2 to 6 that apparently also play an important role in the maturation of chondrocytes in vivo ( $\mathrm{Ju}$ et al. 2000; Kaps et al. 2002). We have had good experience in our previous experiments with the differentiation procedure used in our study (Miura 2002).

We chose the surgical procedure and method of creating the iatrogenic defect of the growth cartilage on the basis of good experience with the methodology used in our previous experiments (Gál et al. 2002ab; Gál et al. 2007; Plánka et al. 2007) and in similar studies of other authors (Ahn et al. 2004; Chen et al. 2003).

Radiological examination is readily accessible and allows determining with a relatively high accuracy both the length of the X-rayed bone and its possible angular deformity. The method of measuring the femur length in the pig was based on Janarv's original study (Janarv et al. 1998), whereas the measuring of the extent of valgus deformity had been consulted with specialists on descriptive geometry for the needs of earlier studies of the authors (Gál et al. 2007; Plánka et al. 2007). 
Histological examination of microsections stained with haematoxylin and eosin (HE) gives a reliable answer as to the character and quality of cartilage in iatrogenically created defects. The results of our examinations were fully in accordance with the established hypothesis and also corresponded with the results of several similar studies (Ahn et al. 2004; Chen et al. 2003).

In the experiments the filling of the growth cartilage defects with chondrocytes or stem cells was mostly performed immediately after they were created (Ahn et al. 2004; Chen et al. 2003; Gál et al. 2002a; Plánka et al. 2007). It was thus a prevention of the bone bridge formation, as in the case of animals of Group A in this study. The results of our previous study (Plánka et al. 2007) document successful differentiation of MSCs into chondrocytes in vivo and also point out the possible clinical importance of MSC transplantation in the sense of healing an iatrogenically created defect in the distal growth zone of the femur while maintaining (recovering) the growth of the damaged bone lengthwise and restricting the development of angular deformity of the affected bone that accompanies cases of partial closure of the growth plate.

It is less frequent in experiments that chondrocytes or MSCs are transplanted after the excision of an already formed bone bridge in the growth cartilage (Gál et al. 2002b; Hui et al. 2005), i.e. that the bone bridge is treated.

The purpose of this study on pigs was to compare which one of the aforementioned approaches to treating injury of the cartilaginous growth plate is more efficient from the viewpoint of possible recovery of the lengthwise growth of the affected bone and restriction of the development of its angular deformity. Therefore, we evaluated the effect of preventive (Group A) vs. therapeutic (Group B) transplantation of MSCs on the lengthwise bone growth and its valgus deformity after creating an iatrogenic partial defect of the distal physis of the femur. To our knowledge, no studies have yet dealt with a mutual comparison of the preventive and therapeutic methods of treating the injured growth cartilage. Based on the results we found, it may be stated that both methods have a positive effect on the lengthwise bone growth and also restrict the development of its angular deformity. These findings are in accordance with partial findings of previous experiments (Ahn et al. 2004; Chen et al. 2003; Plánka et al. 2007; Hui et al. 2005). The results of this study apparently show that preventive transplantation of allogeneic MSCs (i.e. transplantation immediately after a physeal injury) should lead to a better effect than the "belated" therapeutic transplantation of stem cells (i.e. only after the excision of an already formed bone bridge), especially with regard to further lengthwise growth of the affected bone. The question remains as to the actual importance of the use of the preventive transplantation of MSCs for the extent of reducing the development of angular deformity; our findings do demonstrate a difference in valgus deformity when using these two approaches to treating a physeal growth zone injury, however, this difference was not significant $(p=0.586)$. This finding may have been influenced e.g. by the age of the animal at the time of transplantation of MSCs, or may be specific to individual species of animals, therefore it appears desirable to address this issue in further studies. Yet in any case, all transplantations of MSCs require a suitable type of scaffold and appropriate number of stem cells in the given implant (i.e. previously verified procedures in vitro and in vivo that may be specific to individual cytologic laboratories engaging in the preparation of stem cells), if their use with the relevant indication is to be successful.

As concerns the choice of treatment of a traumatic closure of physeal plates, the facts we found may influence future strategy of a possible approach to this issue in clinical practice.

A certain advantage from the view point of executing preventive intervention in the form of transplantation of MSCs into a physeal injury may be the use of allogeneic stem cells. This approach requires having at a disposal the relevant tissue bank. In the case of elective 
transplantation of MSCs into physeal injuries, both auto- and allotransplant may be used. However, based on experience from experimental conditions, for cultivation of a sufficient number of autotransplant cells a time period of approximately 3 weeks is necessary from the time of their sampling (Grande et al. 1995; Ahn et al. 2004).

Allotransplantation of MSCs appears more perspective from the practical point of view also because, as appears from available data, it may not be necessary to eliminate the immune response of the receptor (Batten et al. 2006; Plumas et al. 2005; Caparrelli et al. 2004; Gál et al. 2007). Moreover, the immunomodulatory effect of MSCs has been described in the form of CD4+ T lymphocytes inactivation (Batten et al. 2006; Plumas et al. 2005; Frank and Sayegh 2004).

Preventive transplantation of mesenchymal stem cells into a partial defect of the distal growth zone of the femur in pigs appears more suitable in comparison with the therapeutic transplantation with regard to a more pronounced lengthwise bone growth. A prerequisite for the preventive use of MSCs is the availability of allogeneic cells (tissue bank). The differences found in the extent of valgus deformity of the distal segment of the bone when comparing preventive and therapeutic transplantations of MSCs were non-significant. At the same time, we found that both methods of transplantation have a positive effect on the lengthwise growth of the injured bone and also restrict the development of its angular deformity. Therefore, their use may be considered in the future even in clinical cases, however, only after further experimental verification and thorough evaluation of all the aspects of a safe use of MSC transplants in patients.

\section{Srovnání preventivní a terapeutické transplantace alogenních mezenchymových buněk při hojení defektů distální růstové chrupavky femuru u miniaturních prasat}

Cílem této práce bylo ověřit, zda dochází k rozdílu v růstu femuru do délky a jeho angulární deformitě při srovnání preventivní a terapeutické transplantace alogenních mesenchymových kmenových buněk (MSCs) do iatrogenního defektu distální fýzy femuru.

Skafold MSCs z modifikovaného kompozitu chitosanu/kolagenu typu I byl transplantován do iatrogenně vytvořeného defektu růstové chrupavky v laterálním kondylu levého femuru u 20 samců miniaturních prasat. Ve skupině zvířat A $(n=10)$ byly alogenní MSCs transplantovány okamžitě po vytvoření defektu v distální fýze femuru (preventivní transplantace). Ve skupině $\mathrm{B}(\mathrm{n}=10)$ byl tentýž defekt růstové chrupavky ošetřen transplantací alogenních MSCs čtyři týdny po jeho vytvoření (terapeutická transplantace), po excizi kostního můstku, jenž se v něm utvořil.

Levé femury s poškozenou distální fýzou a preventivně transplantovanými MSCs (skupina A) vyrostly během 4 měsíců od transplantace průměrně o $0,56 \pm 0,44 \mathrm{~cm}$ více než pravé femury bez transplantace MSCs, zatímco levé femury s fyzárním defektem ošetřeným terapeutickou transplantací alogenních MSCs (skupina B) pouze o 0,14 $\pm 0,72 \mathrm{~cm}$ ve srovnání s pravými femury bez transplantace MSCs.

Čtyři měsíce po preventivní transplantaci MSCs (skupina A) byla valgózní deformita distální části levého femuru s defektem $0,78 \pm 0,82^{\circ}$; u kontrolní skupiny (pravý femur téhož zvířete bez transplantace MSCs) 3,7 $\pm 0,82^{\circ}$. Po terapeutické transplantaci MSCs (skupina B) 0,6 $\pm 3,4^{\circ}$, u kontrolní skupiny (pravý femur téhož zvířete bez transplantace MSCs) $2,1 \pm 2,9^{\circ}$.

U všech zviŕat skupiny A i B byla histologicky a imunohistochemicky v oblasti levého distálního femuru potvrzena přítomnost nově utvořené hyalinní chrupavky na místě původního defektu růstové chrupavky po transplantaci alogenních MSCs. V distální fýze pravého femuru s iatrogenním defektem růstové chrupavky bez transplantace MSCs (kontrola) se utvořil kostní můstek.

Preventivní transplantace alogenních MSCs do defektu distální růstové zóny femuru se 
jeví vhodnější v porovnání s terapeutickou transplantací vzhledem $\mathrm{k}$ výraznějšímu růstu kosti do délky. Rozdíly zjištěné v rozsahu valgózní deformity nebyly při srovnání preventivní a terapeutické transplantace MSCs signifikantní.

\section{Acknowledgement}

This work was supported by the Ministry of Health of the Czech Republic (Research Projects of IGA MZ CR NR9296-2/2007) and the Ministry of Education, Youth and Sports of the Czech Republic (NPV II 2B06130) and by the Grant Agency AGEL-MH.

\section{References}

Ahn JI, Canale TS, Butler SD, Hasty KA 2004: Stem cell repair of physeal cartilage. J Orthop Res 22: 1215-1221

Batten P, Sarathchandra P, Antoniw JW, Tay SS 2006: Human mesenchymal stem cells induce T cell anergy and downregulate $\mathrm{T}$ cell allo-responses via the TH2 pathway: relevance to tissue engineering human heart valves. Tissue Eng 12: 2263-2273

Bright RW 1974: Operative correction of partial epiphyseal plate closure by osseous-bridge resection and siliconrubber implant. J Bone Joint Surg Am 56: 655-664

Caparrelli DJ, Cattaneo E, Shake JG 2004: Cellular cardiomyoplasty with allogenic mesenchymal stem cells results in improved cardiac performance in a swine model of myocardial infarction. Circulation 104: 11-59

Frank MH, Sayegh MH 2004: Immunomodulatory functions of mesenchymal stem cells. Lancet 363: 1411

Foster BK, Hansen AL, Gibson GJ, Hopwood JJ, Binns GF, Wiebkin OW 1990: Reimplantation of growth plate chondrocytes into growth plate defects in sheep. J Orthop Res 8: 555-564

Gál P, Nečas A, Adler J, Teyschl O, Fabián P, Bibrová S 2002a: Transplantation of the autogenous chondrocyte graft to physeal defects: an experimental study in pigs. Acta Vet Brno 71: 327-332

Gál P, Teyschl O, Kecová H, Fabián P, Bibrová S 2002b: The influence of transphyseal pin placement on bone growth: an experimental study in pigs. Acta Vet Brno 71: 319-325

Gál P, Nečas A, Plánka L, Kecová H, Křen L, Krupa P, Hlučilová J, Usvald D 2007: Chondrocytic potential of allogenic mesenchymal stem cells transplanted without immunosuppression to regenerate physeal defect in pigs. Acta Vet Brno 76: 253-263

Grande DA, Southerland SS, Manji R, Pate DW, Schwartz RE, Lucas PA 1995: Repair of articular cartilage defects using mesenchymal stem cells. Tissue Eng 1: 345-353

Hideya Y, Takeshi M, Akimoto N, Akiko Y, Hideyuki K, Ichiro S 2007: Comparison of rat mesenchymal stem cells derived from bone marrow, synovium, periosteum, adipose tissue, and muscle. Cell Tissue Res 327: $449-462$

Hui JHP, Li L, Teo YH, Ouyang HW, Lee EH 2005: Comparative study of the ability of mesenchymal stem cells derived from bone marrow, periosteum, and adipose tissue in treatment of partial growth arrest in pig. Tissue Eng 11: 904-912

Chen F, Hui JH, Chan WK, Lee EH 2003: Cultured mesenchymal stem cell transfers in the treatment of partial growth arrest. J Pediatr Orthop 23: 425-429

Chen G, Liu D, Tadokoro M, Hirochika R, Ohgushi H, Tateishi T, Tanaka J 2004: Chondrogenic differentiation of human mesenchymal stem cells cultured in cobweb-like biodegradable scaffold. Biochem Biophys Res Commun 322: $50-55$

Janarv PM, Wikström B, Hirsch G 1998: The influence of transphyseal drilling and tendon grafting on bone growth: an experimental study in the pig. J Pediatr Orthop 18: 149-154

Ju W, Hoffmann A, Verschueren K, Tylzanowski P, Kaps C, Gross G, Huylebroeck D 2000: The bone morphogenetic protein 2 signaling mediator Smad1 participates predominantly in osteogenic and not in chondrogenic differentiation in mesenchymal progenitors C3H10T1/2. J Bone Miner Res 15: 1889-1899

Kaps C, Bramlage C, Smolian H, Haisch A, Ungethum U, Burmester Gr, Sittinger M, Gross G, Haupl T 2002: Bone morphogenetic proteins promote cartilage differentiation and protect engineered artificial cartilage from fibroblast invasion and destruction. Arthritis Rheum 46: 149-162

Katayama R, Wakitani S, Tsumaki N, Morita Y, Matsushita I, Gejo R, Kimura T 2004: Repair of articular cartilage defects in pigs using CDMP1 gene-transfected autologous mesenchymal cells derived from bone marrow. Rheumatology 43: 980-985

Key JA, Ford LT 1958: A study of experimental trauma to the distal femoral epiphysis in rabbits. II. J Bone Joint Surg Am 40: 887-896

Langenskiöld A 1981: Surgical treatment of partial closure of the growth plate. J Pediatr Orthop 1: 3-11

Lee EH, Chen F, Chan J, Bose K 1998: Treatment of growth arrest by transfer of cultured chondrocytes into physeal defects. J Pediatr Orthop 18: 155-160

Lee JW, Kim YH, Kim SH, Han SH, Hahn SB 2004: Chondrogenic differentiation of mesenchymal stem cells and its clinical applications. Yonsei Med J 45: 41-47

Lennox DW, Goldner RD, Sussman MD 1983: Cartilage as an interposition material to prevent transphyseal bone bridge formation: an experimental model. J Pediatr Orthop 3: 207-210 
Li WJ, Tuli R, Okafor C, Derfoul A, Danielson KG, Hall DJ, Tuan RS 1993: A three-dimensional nanofibrous scaffold for cartilage tissue engineering using human mesenchymal stem cells. Biomaterials 26: 599-609

Lisignoli G, Cristino S, Piacentini A, Toneguzzi S, Grossi F, Cavallo C, Zini N, Solimando L, Naraldi NM, Ficchini A 2005: Cellular et molecular events during chondrogenesis of human mesenchymal stromal cells grown in three-dimensional hyaluronan based scaffold. Biomaterials 26: 5677-5686

Mackay AM, Beck SC, Murphy JM, Barry FP, Chichester CO, Pittenger MF 1998: Chondrogenic differentiation of cultured human mesenchymal stem cells from marrow. Tissue Eng 4: 415-428

Macksoud WS, Bright R 1989: Bar resection and Silastic interposition in distal radial physeal arrest. Orthop Trans 13: 1-2

Mann DC, Rajmaira S 1990: Distribution of physeal and nonphyseal fractures in 2,650 long-bone fractures in children aged 0-16 years. J Pediatr Orthop 10: 713-716

Miura Z, Parvizi J, Fitzsimmons JS, O’Driscoll SW 2002: Brief exposure to high-dose transforming growth factor-beta1 enhances periosteal chondrogenesis in vitro: a preliminary report. J Bone Joint Surg Am 84: 793-799

Plánka L, Nečas A, Gál P, Kecová H, Filová E, Křen L, Krupa P 2007: Prevention of bone bridge formation using transplantation of the autogenous mesenchymal stem cells to physeal defects: An experimental study in pigs. Acta Vet Brno 76: 257-266

Plumas J, Chaperot L, Richard MJ, Molens JP 2005: Mesenchymal stem cells induce apoptosis of activated T cells. Leukemia 19: 1597

Sýkora I, Dynterová A, Holda J, Marhan O 1983: Chov laboratorních zvířat. Institut výchovy a vzdělávání MZVž Praha. 
Plate XIII

Plánka L. et al.: Comparison ... pp. 293-302

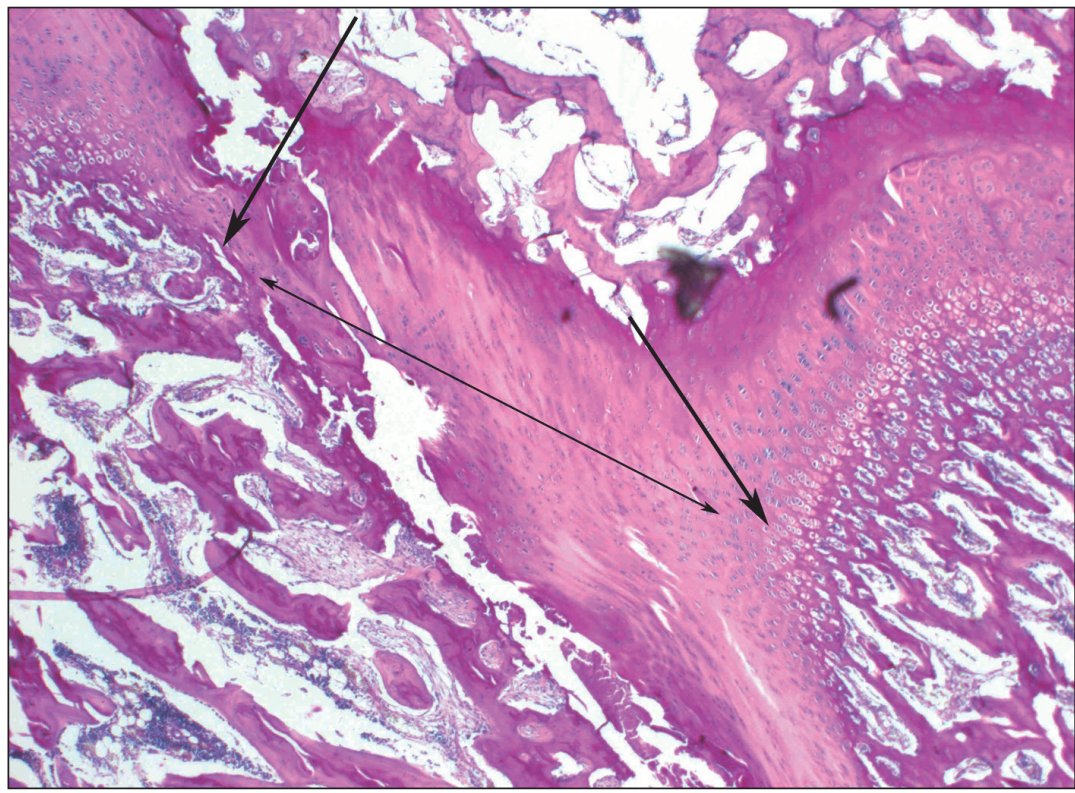

Fig. 1. Histological examination of the left distal femoral physis in pigs after preventive allogeneic MSC transplantation (PAS stain, magnification, $\times 40$ ). The wide arrows show the borders of the physeal defect, the narrow arrow shows the defect formation filled with the hyaline cartilage (pig A2).

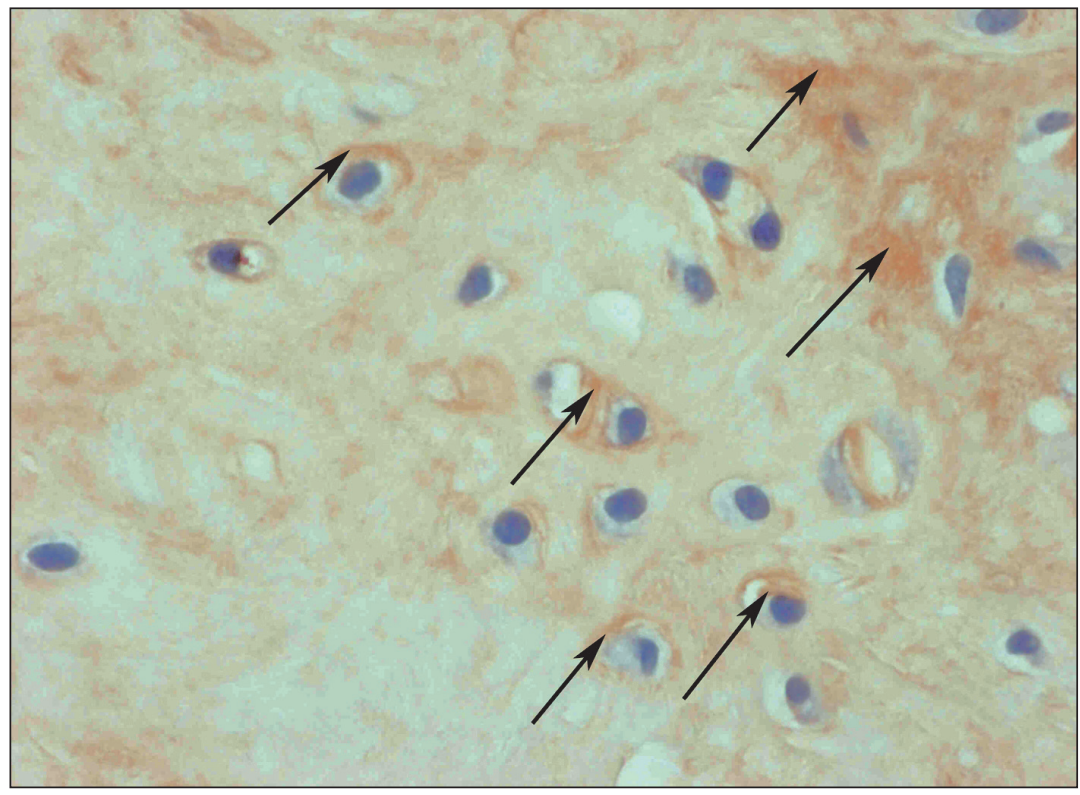

Fig. 2. Immunofluorescence stain DiI on chondrocyte membranes (arrows) differentiated from implanted allogeneic MSCs (pig B12) $(\times 400)$. Histological examination of the left distal femoral physis in pigs after preventive allogeneic MSC transplantation (CII A imunohistochemistry, magnification, $\times 400$ ). The black arrows show the positive reaction with CII antibodies (pig A6). 


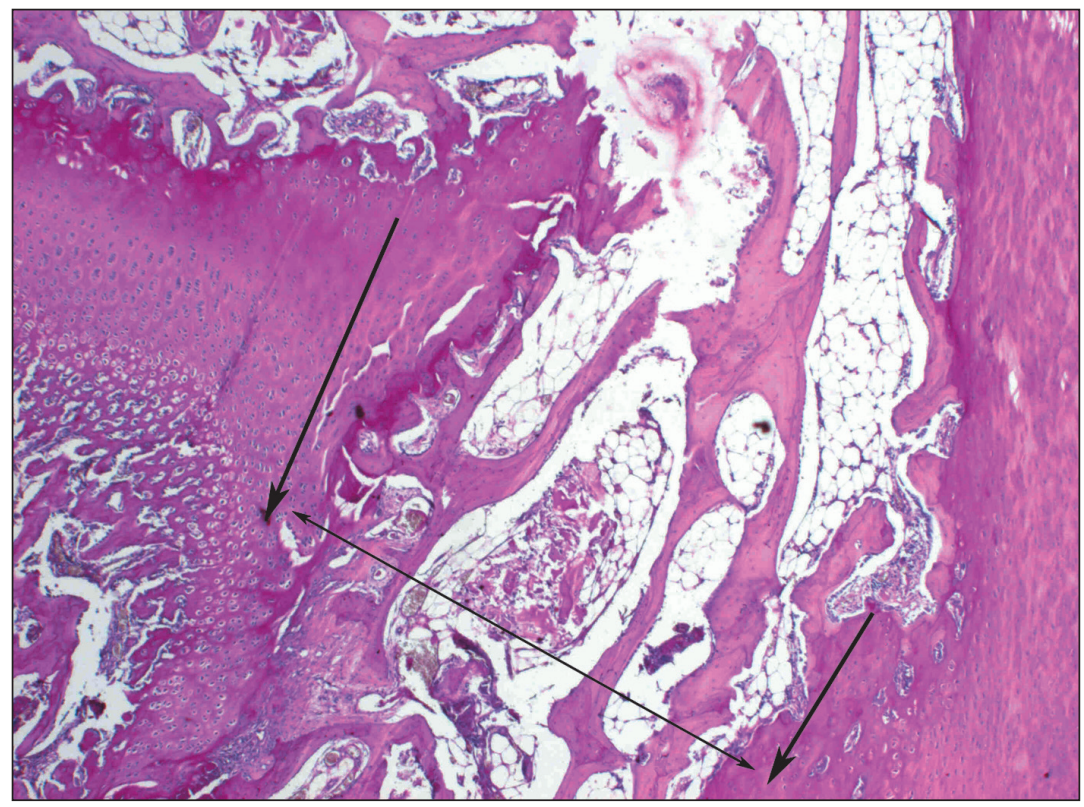

Fig. 3. Histological examination of the right distal femoral physis in pigs - control group (PAS stain, magnification, $\times 40$ ). The wide arrows show the borders of the physeal defect, the narrow arrow shows the defect formation filled with bone bridge (pig B5) 